\title{
Examining mortality differentials between a long-living community in Sardinia and the Italian population: a longitudinal analysis
}

Luisa Salaris - University of Cagliari

salaris@unica.it

(Received May 2014 Revised October 2014)

http://dx.doi.org/10.14301/llcs.v6i1.304

\section{Abstract}

Progressive gains in life expectancy have brought increasing aging of developed countries' populations and stimulated researches with respect to the limit of lifespan, the increasing presence of centenarians and the possible determinants of their "successful" ageing. In the international framework the population of the region of Sardinia was characterized by exceptional longevity. Through the comparison of life tables' rates and life expectancy estimates of birth cohorts born in the period 1872-1910, this paper reports analyses of differences in overall mortality between Italy and the long-living community of Sardinia. The adoption of a longitudinal approach allows us to explore whether the previously detected differences at advanced ages are also observable in other age groups. In addition, the study focuses on the occurrence of mortality crossover as an indicator of significant mortality differences between populations. Results show that differences between the two populations are not limited to oldest old ages. Crossover points in mortality rates are observed in the first years of life and at age 50 years. Both intersections represent the points where differences in life expectancy are the highest. At age 5 years differences are of 1.8 years for females and 3.6 years for males, while at age 50 years they are respectively 1.5 years for females and 3.7 years for males. The observed differences suggest that possible explanations for differential mortality and crossover might be related to selection process timing and dynamics which could be determined by genetics, and specific causes of death, as well as by behavioural and environmental factors.

Keywords: differential mortality; crossover; longitudinal analysis; life table; Italy.

\section{Introduction}

In recent decades, continuous improvements achieved in human survival have stimulated studies and researches in various disciplines about the limit of lifespan (Olshansky et al., 1990; Parsons, 1996; Kannisto, 1996; Robine et al., 1997; Gavrilov \& Gavrilova 2001; Vallin \& Meslé, 2001; Carnes et al., 2003; Barbi et al., 2008), the increasing presence of centenarians and their main characteristics (see, among others, Jeune \& Vaupel, 1995; Vaupel, 2000;
Vaupel \& Robine, 2002; Coles, 2003; Robine \& Caselli 2005; Maier et al., 2010) and the possible determinants of their "successful" ageing (see, among others, Allard et al., 1996; Franceschi et al., 2000; Caselli \& Lipsi, 2006; Willcox et al., 2006; Christensen et al., 2006; Franceschi et al., 2007; Murabito et al., 2012; Brooks-Wilson, 2013).

In the international framework, it has been shown that certain populations are characterized by exceptional levels of longevity (Poulain et al., 2013). 
These include Okinawa in Japan (Willcox et al., 2001; Robine et al., 2003; Poulain \& Naito, 2004; Cheung \& Robine, 2007; Poulain, 2011), the peninsula of Nicoya in Costa Rica (Rosero-Bixby, 2008; Davinelli et al., 2012; Rehkopf et al., 2013), and the region of Sardinia in Italy (Deiana et al., 1999; Passarino et al., 2001; Poulain et al., 2004, 2011; Gatti \& Salaris, 2004; Caselli \& Lipsi, 2006; Caselli et al. 2006; Salaris, 2010, 2014; Orrù, 2011; Pes et al., 2013; Salaris et al., 2013).

Sardinia has been the subject of several studies on longevity, as it is generally considered a suitable setting: i) for genetic studies, due to its geographical and genetic isolation (Cavalli Sforza et al., 1997; Lampis et al., 2000; Fraumene et al., 2003; Pilia et al., 2006; Strait et al., 2009); ii) for studies of cardiovascular diseases (CVD), given the low mortality rates recorded in the island (Caselli \& Lipsi, 2006; Muntoni et al., 2009; Scuteri et al., 2009); iii) for researches on centenarians, found to be geographically limited to the inland area of the region (Poulain et al., 2004; Gatti \& Salaris, 2004; Orrù, 2011); iv) for studies of oldest ages in male survival in general (Passarino et al., 2001; Poulain et al., 2011).

The aim of this current contribution is to improve understanding of mortality differentials between Italy and one of the identified and documented long-living communities in Sardinia, namely the municipality of Villagrande Strisaili (section 3), through the comparison of mortality trajectories of historical birth cohorts born in the period 1872-1910 (section 4).

A longitudinal perspective allows us to overcome the age fragmentation that analysis of differential longevity usually involves, as the focus is generally limited to oldest old ages, and so extends the comparison to the entire life span. This approach helps in understanding how mortality trajectories evolve in the two populations over the life course and to look at the different levels of longevity observed, particularly among males, as the outcome of a more complex process which is influenced by the pace and intensity of mortality at earlier ages. The research questions that arise are therefore the following: are the detected differences at advanced ages also present in the other age groups? Or does mortality risk variation across the life course lead to the occurrence of mortality crossovers?
With this aim, the study extends the analysis of mortality age variations in the two settings to the entire life course, including the study of early and young-adult mortality, and devoting special attention to the detection of possible mortality convergence points as indicators of significant changes in mortality risk associated with age (section 5). The study finally sets out the possible explanations for differential survival and mortality crossover between the studied populations (section 6).

\section{Differential mortality and mortality crossover}

In the study of differential mortality researchers have often focused on the so-called mortality crossover, which is usually detected through the comparison of mortality rates. It is considered an indicator of significant variations in mortality risk associated with age. It is not such an unusual event (Liu \& Witten, 1995), as differences in mortality between populations or population subgroups rarely stay constant, but rather produce intersection points (Liu et al., 2008). The crossover occurs at the age of highest difference and corresponds to the shift, for the initially advantaged population, from relatively low to relatively high mortality rates and it is determined by a mortality acceleration (Hirsch et al., 2000).

A growing body of literature has documented mortality crossover in different populations suggesting several factors are responsible for the observed intersection and convergence of mortality rates. Among the relevant factors race and ethnicity are the most studied. Often the analysis looks with interest at the role of specific causes of deaths (Nam et al., 1978; Nam, 1995; Hummer 1996; Corti et al., 1999; Johnson, 2000; Hill et al., 2000; Lynch et al., 2003; Thornton, 2004; Stansbury et al., 2005) and at socioeconomic status (Hoffmann, 2005; Yao \& Robert 2011; Sautter et al., 2012). Crossover proves also to be caused by selection effects of exceptional events such as famine (Song, 2010) and it was detected when comparing particular longliving regions - as for example in Okinawa - with the national framework (Poulain \& Naito, 2004; Poulain, 2011).

There are two major scientific hypotheses for the occurrence of a mortality crossover. The first explanation considers the issue of data quality. Bad data, and particularly age misreporting, leads to 
false mortality crossover (Coale \& Kisker, 1986; Elo \& Preston, 1994; Preston et al., 1999). The second school of thought interprets it in terms of frailty. The population is assumed to be highly heterogeneous and a selection process occurs over the life cycle; frail individuals are eliminated early on, while robust subgroups survive to older ages (Vaupel et al., 1979).

As argued by Lynch et al. (2003; pg. 457) "mortality crossover, however, is only one aspect of mortality that can be considered when evaluating differences between populations. Mortality compression and deceleration - the rate at which the mortality hazard curve changes shape (steepens) across time and the age at which mortality rates cease to grow exponentially across age - constitute important aspects of mortality that must also be considered to understand overall mortality pattern differences".

In particular, the concept of mortality deceleration is related to that of unobserved heterogeneity and of mortality selection (WrigleyField, 2012), as population mortality rates change according to the changing composition of the population. Timing and characteristics of mortality selection might be due to genetic and biological features of the population, and/or to external factors like wars and epidemics which can produce the so-called "mortality shocks" in a population. However, the latter have been shown to produce their effects in the short term, but do not affect the rate of aging of a population (Zarulli, 2012).

\section{The community of Villagrande Strisaili}

Villagrande Strisaili is located at 700 meters above sea level in the province of Ogliastra in the in-land area of Sardinia and it belongs to the so called Blue Zone of longevity in Sardinia, which consists of 14 municipalities where a significant number of centenarians were recorded as well as a low sex ratio value (Poulain et al., 2004).

At the first general population census after Italy unified in 1861, the municipality recorded 1,251 inhabitants and a decade later the residents were 1,111 (Angioni et al., 1997). Since 1861 its population grew continuously until the census of 1971, when for the first time there was a reduction in the population. This change has been determined, as in many other communities in the inland area of Sardinia, by important migration flows that during the ' 60 s and '70s triggered the depopulation of smaller centres (Gatti \& Puggioni 1998). In the most recent decades, we continue to observe a declining trend, although - compared to the past - it is mainly a consequence of structural aging of the population, rather than of outmigration flows (Esposito, 2012). According to the latest available ISTAT (2014) data on resident population at January $1^{\text {st }} 2013$, Villagrande has 3,324 inhabitants.

\section{Data and Methods}

\subsection{Birth cohorts studied}

Birth cohorts from 1872 to 1910 for Italy and for Villagrande Strisaili are followed longitudinally from birth to oldest-old ages. The focus on these birth cohorts was firstly determined by data availability, as cohort life table estimates for Italy are accessible from the Human Mortality Database (HMD) since 1872. Secondly, the decision to include birth cohorts until 1910 guarantees that the population under study consists of individuals that today are at least 100 years old and the number of still living individuals is limited in both populations, although the analysis here is limited to survival up to 80 years old. For Villagrande Strisaili, an average of 50 births per year are recorded; the total number of cases considered in the present study in the birth cohorts 1872-1910 are 1,955 of which 1,009 are males and 946 females. Table 1 presents the distribution of deaths and censored cases by age and sex. 
Table 1. Distribution of deaths and censored cases of Villagrande Strisaili birth cohorts 1872-1910 by age and sex

\begin{tabular}{cccccccc} 
& \multicolumn{3}{c}{ MALES } & & \multicolumn{3}{c}{ FEMALES } \\
\cline { 2 - 4 } \cline { 7 - 8 } \cline { 6 - 7 } & Survivors & Deaths & $\begin{array}{c}\text { Censored } \\
\text { cases }\end{array}$ & & Survivors & Deaths & $\begin{array}{c}\text { Censored } \\
\text { cases }\end{array}$ \\
\hline $\mathbf{0}$ & 1.009 & 240 & 7 & & 946 & 241 & 4 \\
$\mathbf{5}$ & 762 & 36 & 1 & & 701 & 36 & 0 \\
$\mathbf{1 0}$ & 725 & 30 & 0 & & 665 & 18 & 0 \\
$\mathbf{1 5}$ & 695 & 32 & 9 & & 647 & 13 & 2 \\
$\mathbf{2 0}$ & 654 & 51 & 11 & & 632 & 29 & 0 \\
$\mathbf{2 5}$ & 592 & 22 & 8 & & 603 & 24 & 2 \\
$\mathbf{3 0}$ & 562 & 25 & 16 & & 577 & 24 & 3 \\
$\mathbf{3 5}$ & 521 & 15 & 6 & & 550 & 18 & 1 \\
$\mathbf{4 0}$ & 500 & 18 & 2 & & 531 & 20 & 0 \\
$\mathbf{4 5}$ & 480 & 24 & 1 & & 511 & 18 & 0 \\
$\mathbf{5 0}$ & 455 & 12 & 0 & & 493 & 12 & 1 \\
$\mathbf{5 5}$ & 443 & 22 & 0 & & 480 & 22 & 0 \\
$\mathbf{6 0}$ & 421 & 26 & 1 & & 458 & 29 & 0 \\
$\mathbf{6 5}$ & 394 & 27 & 0 & & 429 & 35 & 0 \\
$\mathbf{7 0}$ & 367 & 38 & 1 & & 394 & 35 & 0 \\
$\mathbf{7 5}$ & 328 & 77 & 1 & & 359 & 55 & 0 \\
$\mathbf{8 0}$ and over & 250 & 242 & 8 & 304 & 300 & 4 \\
\hline
\end{tabular}

\subsection{Data sources}

Data for Italy were extracted from the Human Mortality Database (HMD) life table estimates by cohort for the total Italian population (including the village of Villagrande Strisaili), which were constructed by HMD using data from official vital statistics and census counts published by the Italian National Statistics Office (ISTAT). The data for birth cohorts in Villagrande Strisaili comes from the VIllagrande Longevity Database (VILD), a reconstructed family database of all individuals born in Villagrande Strisaili from 1866 to 1915, whose survival was in this study observed until 2010 (Salaris, 2010). Data was collected from civil status registers, population registers and parish registers thanks to the availability of the Diocese of Lanusei (with regard to parish registers) and to the Demographic Office of the municipality of Villagrande Strisaili (for all other registers) in accordance with national data privacy regulations and in compliance with the time limits specified therein. Data was aggregated to avoid identification of subjects. Although historical data requires a great effort for data collection, it allows us to take into consideration the entire population, avoiding selection biases introduced by individual consent. All individuals, dead or alive at the time of the study, are considered thanks to their demographic data. The data coverage is complete and with no selection or sampling of population subgroups. This approach allows us to establish a unique link between historical data and current level of longevity. Through the analysis of births, marriages and deaths each individual was followed from birth to death. Data collection covered the period from 1866 to 2010 and provides a level of coverage of $95 \%$ of known survival. Conversely, the remaining $5 \%$ consists of individuals who were born in the village but whose age at death is not known.

\subsection{Data quality}

Life table estimates for Italy are of good quality and the HMD provided researchers with a reliable set of annual complete life table functions (Meslé \& Vallin, 2009). Raw data comes from period data and subsequently was organized by birth cohort 
(Wilmoth et al., 2007). With regard to coverage and completeness of the data, it should be specified that the HMD calculates death rates on the present population and that estimates took into account deaths of Italian residents that occurred abroad, which were proportionately distributed by age. The official statistics did not include information on deaths during World Wars I and II; however, death counts in the HMD were adjusted to include military deaths (Glei, 2009). With regard to life tables for Villagrande Strisaili, data issue is more complex and implied a careful validation process of raw data. In more detail, data validation was considered possible under-registration of births and related deaths (Breschi et al., 2012); the effect of migration flows (Meslé \& Vallin, 2002); and age misreporting (Ewbank, 1981; Preston et al., 1999). Finally, in order not to exclude individuals with partial information on survival, the study set up a censoring strategy, using the last information available (i.e. still living individuals at the end of observation period, migration date, birth of last child, date of marriage, military examination, Confirmation religious ceremony) as a truncation date of the observational window. In this manner individual survival has been at least underestimated. Right truncated cases represent $4.6 \%$ of the population under study and this percentage varies from $7.1 \%$ of males to $1.8 \%$ of females (Table 1).

\subsection{Methods}

HMD life table functions for Italy were calculated by HMD according to their protocol considering the extinct and almost extinct cohort method, which assumes a stationary population and no international migration (Wilmoth et al., 2007). The latter assumption is reasonable only for advanced ages (Meslé \& Vallin, 2002) and it also holds for Villagrande Strisaili (Salaris, 2010). Life tables for the Villagrande Strisaili population have been built according to Preston et al. (2001) formulas for single decrement life tables and estimated separately for males and females. The SPSS software (v. 17.0) was used to obtain basic life table estimates. The analysis considered individual data, which were aggregated by 5-year intervals. Terminal events (deaths) and censored cases (ends of observation) were summed at each 5-year age interval. Mortality rates $\left(m_{x}\right)$ directly derive from the software outputs and were estimated according to the exact exposure time of the individuals involved (exact age at death and at censoring). Life expectancy estimates instead were estimated from the basic life table functions provided by the software. For infants below age 5 years, the formulas used for $a_{0}$ come from adapted values from Coale and Demeny (1983, cited by Preston et al., 2001) for West model life tables as proposed by Preston et al. (2001). For both Italian and Villagrande Strisaili life tables, open age category at 80 years was estimated adopting formulas suggested by Preston et al. (2001: 48) and by the Human Mortality Database Protocol for Cohort Life Tables (Wilmoth et al., 2007).

Due to the limited size of the Villagrande Strisaili population, all birth cohorts in the period 18721910 were analysed as a unique group, using the mean value of the selected life table function for all birth cohorts. The analysis considered the overall mortality level in the two populations, without controlling for other variables. This choice is for some aspects controversial, as it assumes that the survival experience of individuals born over a period of about 40 years is similar and does not take into account the possible confounding effects of individual characteristics and/or cohort experience. However, prior analysis of birth cohort data from Villagrande Strisaili showed that, despite no observation of a secular trend in survival among decennial cohorts, mortality differentials between cohorts were limited to adult ages and shown not to have impacted on the ageing process (Salaris, 2014).

\section{Results}

\subsection{Comparison of mortality rates}

Table 2 reports age-specific mortality rate estimates from birth to age 80 years for Italy and Villagrande Strisaili by sex. The reported rates refer to the average mortality risk at each time interval. Mortality estimates in the two populations converge and intersect in different points but among them two points deserve particular attention as differences proved to be statistically significant. Crossovers are detected in correspondence of curves' intersection (Figure1, Figure 2). 
Table 2. Mortality rates $\left(m_{x}\right)$ comparison for Italy and Villagrande Strisaili birth cohorts by age and by sex

\begin{tabular}{|c|c|c|c|c|c|c|c|}
\hline \multirow{3}{*}{ Age } & \multicolumn{3}{|c|}{ MALES } & \multirow{3}{*}{ Age } & \multicolumn{3}{|c|}{ FEMALES } \\
\hline & \multirow{2}{*}{$\frac{\text { Italy }}{\mathrm{mx}}$} & \multicolumn{2}{|c|}{ Villagrande Str. } & & \multirow{2}{*}{$\begin{array}{c}\text { Italy } \\
\mathbf{m x}\end{array}$} & \multicolumn{2}{|c|}{ Villagrande Str. } \\
\hline & & $m x$ & se & & & $\mathbf{m x}$ & se \\
\hline $0-4$ & 0.0800 & 0.0542 & 0.0035 & 0 & 0.0760 & 0.0585 & 0.0037 \\
\hline $5-9$ & 0.0078 & 0.0097 & 0.0016 & 5 & 0.0083 & 0.0105 & 0.0018 \\
\hline $10-14$ & 0.0036 & 0.0085 & 0.0015 & 10 & 0.0043 & 0.0055 & 0.0013 \\
\hline $15-19$ & 0.0061 & 0.0095 & 0.0017 & 15 & 0.0057 & 0.0041 & 0.0011 \\
\hline $20-24$ & 0.0118 & 0.0164 & 0.0023 & 20 & 0.0067 & 0.0094 & 0.0017 \\
\hline $25-29$ & 0.0093 & 0.0076 & 0.0016 & 25 & 0.0065 & 0.0081 & 0.0017 \\
\hline $30-34$ & 0.0080 & 0.0092 & 0.0018 & 30 & 0.0063 & 0.0085 & 0.0017 \\
\hline $35-39$ & 0.0076 & 0.0059 & 0.0015 & 35 & 0.0060 & 0.0067 & 0.0016 \\
\hline $40-44$ & 0.0079 & 0.0073 & 0.0017 & 40 & 0.0060 & 0.0077 & 0.0017 \\
\hline $45-49$ & 0.0088 & 0.0103 & 0.0021 & 45 & 0.0062 & 0.0072 & 0.0017 \\
\hline $50-54$ & 0.0114 & 0.0053 & 0.0015 & 50 & 0.0077 & 0.0049 & 0.0014 \\
\hline $55-59$ & 0.0161 & 0.0102 & 0.0022 & 55 & 0.0105 & 0.0094 & 0.0020 \\
\hline $60-64$ & 0.0239 & 0.0128 & 0.0025 & 60 & 0.0156 & 0.0131 & 0.0024 \\
\hline $65-69$ & 0.0362 & 0.0142 & 0.0027 & 65 & 0.0243 & 0.0170 & 0.0029 \\
\hline $70-74$ & 0.0557 & 0.0219 & 0.0035 & 70 & 0.0392 & 0.0186 & 0.0031 \\
\hline $75-79$ & 0.0866 & 0.0533 & 0.0060 & 75 & 0.0642 & 0.0332 & 0.0045 \\
\hline $80+$ & 0.1334 & 0.0465 & 0.0064 & 80 & 0.1031 & 0.0636 & 0.0069 \\
\hline
\end{tabular}

Figure 1. Mortality rates $\left(m_{x}\right)$ comparison for Villagrande Strisaili and Italy for female birth cohorts (in logarithmic scale)

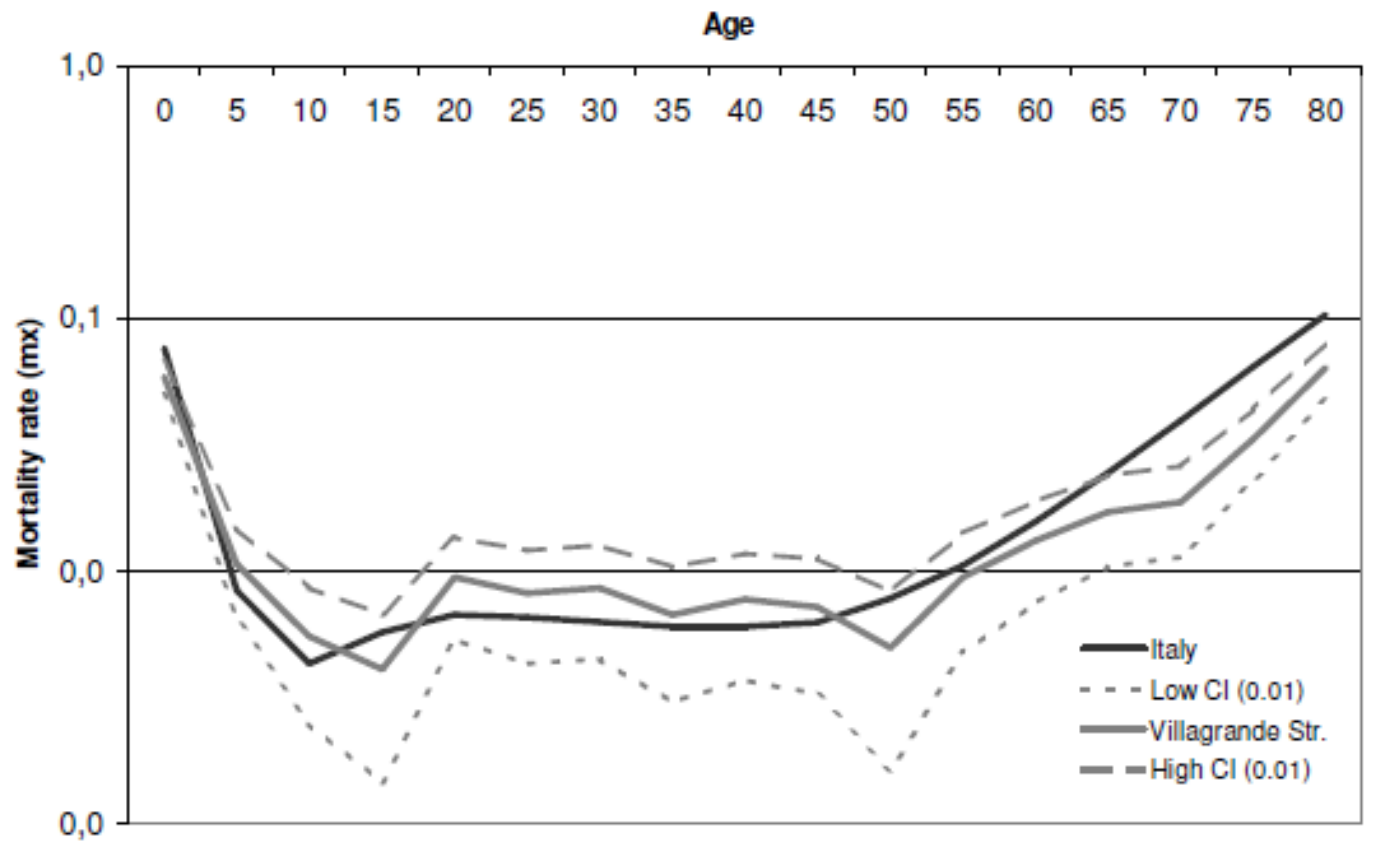


Figure 2. Mortality rates $\left(m_{x}\right)$ comparison for Villagrande Strisaili and Italy for male birth cohorts (in logarithmic scale)

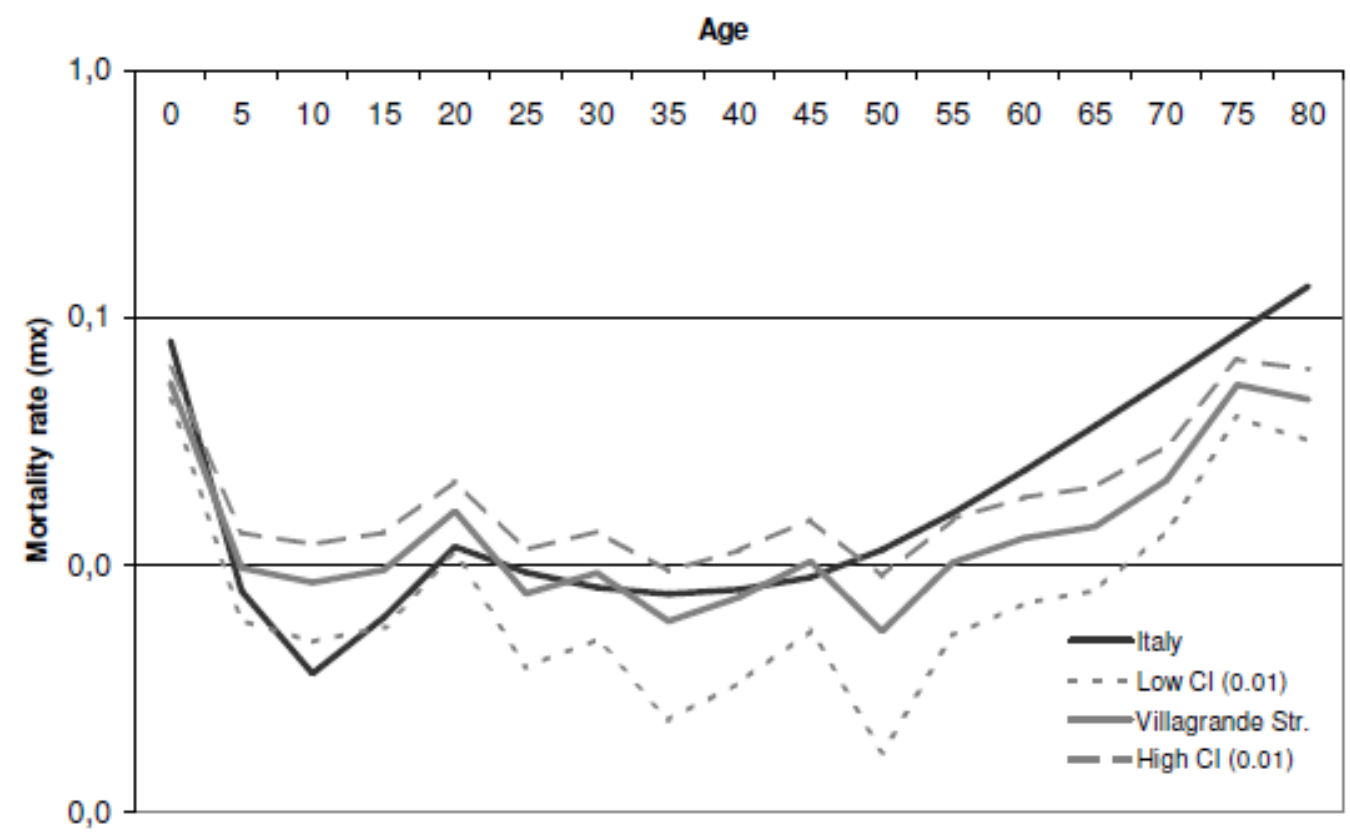

The first intersection point for both males and females is observed in correspondence of age 0 to 4 years old, noting that the risk of death in the first four years of life is lower in Villagrande Strisaili than in Italy. Italian male birth cohorts record 32.3 percent higher mortality rates than their peers born in Villagrande Strisaili, while for females this difference is 23.0 percent.

What appears particularly interesting is that after 5 years old, a worsening of survival conditions in Villagrande Strisaili, compared to the national estimates, is clearly observed. This change proves to be particularly marked for males, who from age 5 to age 20 years in Villagrande Strisaili have increased risk of death. At age 10-14 years the difference in mortality rate are statistically significant and Villagrande Strisaili males experience a 134.3 percent higher risk of death than their national peers.

The mortality rates trend during young adulthood do not markedly differ in the examined populations and estimates converge to similar values. In consequence the proportion of newborns that reach 50 years old is similar in both birth cohorts in Italy and in Villagrande Strisaili: in Italy 47.4 percent of males and 52.1 percent of females; in Villagrande Strisaili 45.1 percent of males and 52.1 percent of females.

Relevant differences again emerge at the onset of ageing when a second relevant crossover can be observed. At age 50 years mortality starts to grow exponentially in both populations and for both sexes. In general, the risk of death for individuals in Villagrande Strisaili is lower than for their national peers. For females, we observed that until age 50 years Villagrande Strisaili records a higher mortality risk and after intersection it experiences a reduced susceptibility to mortality. However, differences between the two populations are not particularly marked and become statistically significant ( $p$-value $=0.01$ ) only after age 65 years. As figure 2 shows, differences between males are particularly marked from age 50 years onwards, and as a person ages the risk of death in Villagrande Strisaili is lower than in Italy. Differences from age 55 years are statistically significant ( $p$-value $=0.01$ ) and are estimated to be 37 percent higher for the Italian population than for Villagrande Strisaili.

\subsection{Differences in life expectancy}

Figure 3 and Figure 4 show life expectancy $\left(e_{x}\right)$ estimates for Villagrande Strisaili and Italian birth cohorts from birth to 80 years, respectively for females and males. Although differences might appear limited (especially between females), the values represented according to the second $y$-axis on the right side of the graphs show more clearly when and how the two populations differ in terms of survival. 
Figure 3. Female life expectancy estimates for Villagrande Strisaili and Italian birth cohorts (1872-1910)

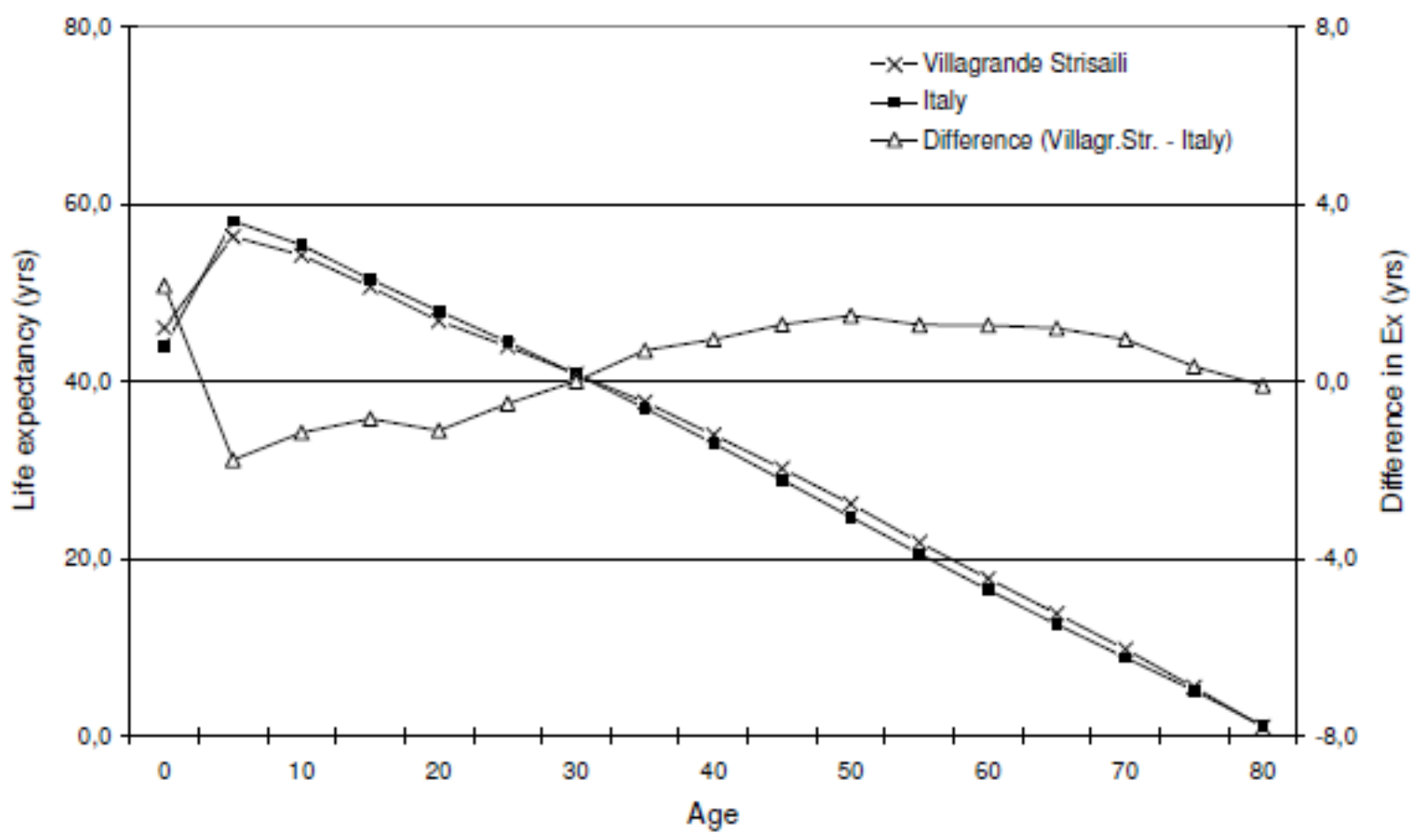

Figure 4. Male life expectancy estimates for Villagrande Strisaili and Italian birth cohorts (1872-1910)

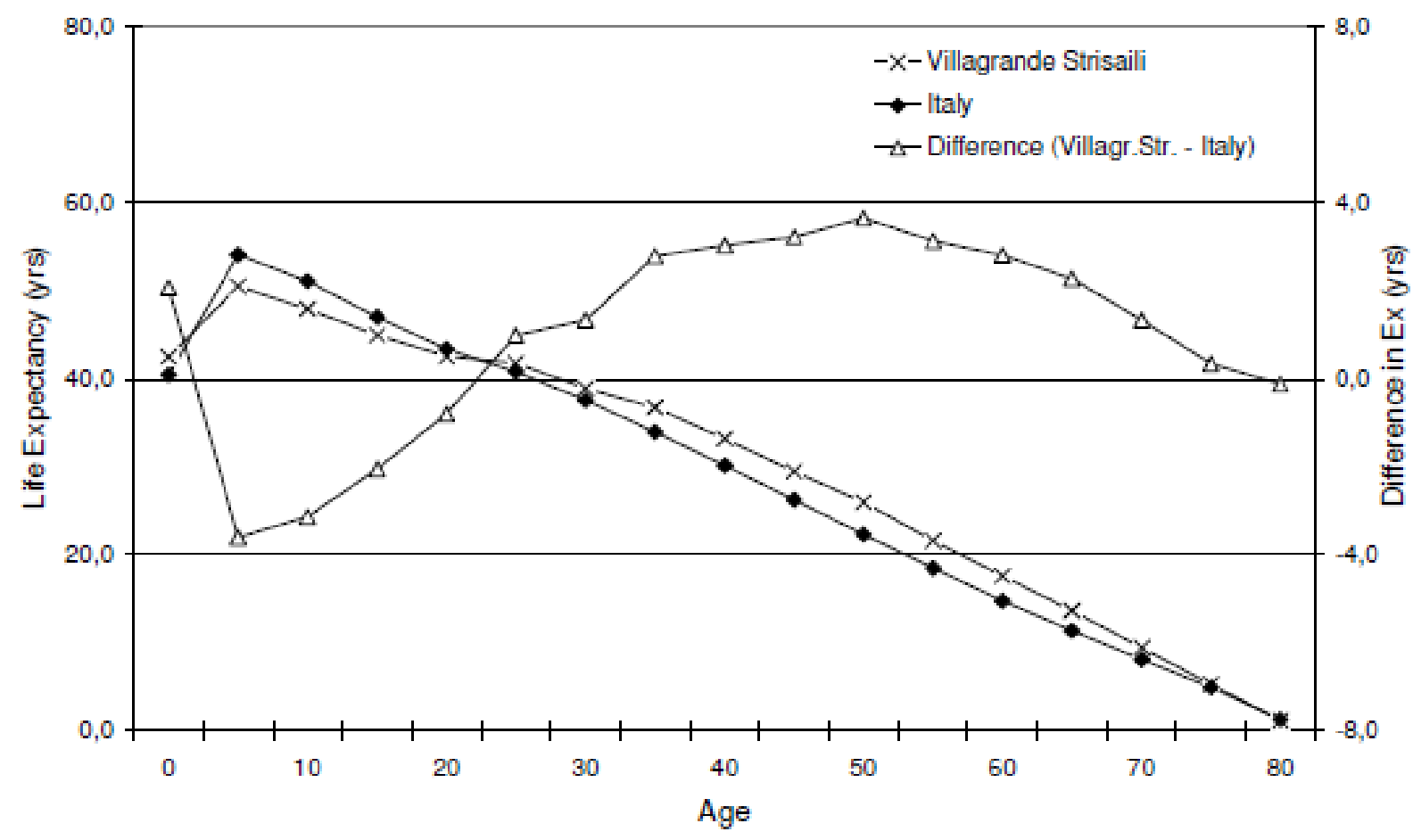


Life expectancy $\left(e_{\mathrm{x}}\right)$ at birth for females is 46.1 years for individuals born in Villagrande Strisaili and 43.9 years for their Italian peers. For males, in Villagrande Strisaili an $e_{x}$ value of 42.5 years and for Italy 40.4 years are recorded, underlining a slightly higher life expectancy at birth in Villagrande Strisaili than in Italy. At birth, differences are 2.2 years for females and 2.1 years for males.

At age 5 years females have an $e_{x}$ of 56.3 years for Villagrande Strisaili and 58.1 for Italy, while among males $e_{x}$ at the same age is 50.5 years for Villagrande Strisaili and 54.1 years for Italy. Differences are from 1.8 years among females to 3.6 years among males and this produces an intersection of the two $e_{x}$ curves at 5 years old. From age 5 years to adulthood (20-30 years) $e_{x}$ estimates for the Italian population are higher than for Villagrande Strisaili and the two $e_{x}$ curves intersect at age group 20-25 years for males and at age group 30-35 years for females. This higher mortality recorded in Villagrande Strisaili during this age period could be the result of a postponement of early death. Therefore, the survival advantage recorded in Villagrande Strisaili in the first year of life - as evidenced in the analysis of mortality rates - is not maintained at subsequent ages, but generates an excess mortality during the transition from childhood to adulthood.

Since the crossover point between the $e_{x}$ curves of females is at 25 years, Villagrande Strisaili and Italian birth cohort estimates proceed as two parallel lines. At age 50 years the highest difference is recorded in the two populations and $e_{x}$ of females in Villagrande Strisaili exceeds estimates for the female Italian population by 1.5 years. Differences are more marked for males, where the crossover occurs earlier at age 20 years. Starting from that age the excess of life expectancy of Villagrande Strisaili males varies from 1.0 years at 25 years and reaches a maximum at age 50 years when the difference between Villagrande Strisaili and the Italian population is 3.7 years, suggesting that the two populations greatly differ at the onset of the aging process.

\section{Discussion}

The adoption of a longitudinal perspective for the study of mortality differential between a longliving community in Sardinia and the Italian population confirms prior findings which pointed out that at more advanced ages the two populations present a different level of susceptibility to mortality (Caselli \& Lipsi, 2006; Poulain et al., 2011). However, the differences are shown not to be limited exclusively to the oldest old ages.

Firstly, the results of this analysis show that the inclusion of all age groups, from birth to 80 years old, allows us to detect the occurrence of two relevant points of crossover. On the one hand, this result points out differences in mortality variations during the life course in the examined populations, but - on the other hand - it calls into question the appropriateness of a comparison of populations so different in size, as well as the quality of the data (Coale \& Kisker, 1986; Scherbov \& Ediev, 2011). With respect to the first factor, the available period data on general mortality level shows that the mortality experiences of the examined populations have similar profiles (Salaris, 2014). There are no significant differences in the impact of important historical events like WWI, WWII and Spanish flu epidemic (Tognotti, 1996; Cannas, 2007; Salaris, 2010). Moreover, the examined birth cohorts despite the observed differences in early and young adult mortality - record similar proportions of survivors that reach 50 years old.

The first crossover occurs in the first years of life. At age 5 years differences in life expectancy are of 1.8 years for females and 3.6 years for males, lower in Villagrande Strisaili compared to Italy. A second marked intersection takes place at age 50 years, where differences are respectively of 1.5 years for females and 3.7 for males, but this time life expectancy is higher in Villagrande Strisaili compared to national estimates. The observed differences in mortality in the first years of life raise questions about data quality and in particular about the possible distorting effect of errors in registration of stillbirths and infant deaths. As discussed in detail in section 4 , on the one hand it is not possible to exclude this type of bias (Breschi et al., 2012) as so far, given the poor living conditions experienced on the island at the turn of the $20^{\text {th }}$ century, it is difficult to find a convincing explanation for this phenomenon of low early mortality. However, on the other hand, numerous studies at the macro and micro levels have confirmed the particularly favourable situation for early survival in Sardinia and the good quality of the data (Coletti, 1908; Bellettini, 1987; Pozzi, 2000; Gatti, 2002; Salaris, 2010). To overcome possible 
biases in early mortality estimation in Villagrande Strisaili, individual data on possible cases of underregistration of births and related deaths as well as the effects of migration flows were carefully examined.

The second crossover point takes place at age 50 years and this result appears to be robust with regard to data, as it depends on ageing mechanisms of survivors. The data used for Villagrande Strisaili was submitted to a rigorous validation procedure to avoid cases of age misreporting and to achieve the maximum level of complete information on survival, assuring good quality of the data we used. This allowed us to exclude the occurrence of a false crossover related to poor data coverage, completeness and quality.

Secondly, in this study the observed differences in mortality rates suggest that a possible explanation of differential mortality and crossover might be related to selection processes, timing and dynamics. In this perspective the longitudinal approach turns out to be particularly useful to better understand mortality age variations across the life course in the examined populations.

The occurrence of first crossover - observed in the first years of life - might be explained by what happens after age 5 years. In Villagrande Strisaili, in fact, from age 6 years to adulthood an excess mortality of its population particularly for males compared to Italy is observed. This means that the postponement effects of early mortality from the first two years of life to subsequent ages observed by numerous researchers on Sardinian data until age 5 years - the conventional limit for the study of child mortality - in actual fact also continues after this age. The initial favourable conditions for children that have been observed in Sardinia prove therefore to be temporary. This result might be explained by the changing attitude that parents in Sardinia had towards their children once they reached 2 years old as documented by Coletti (1908). The author reports that children experienced an obsessive care in the first years of life, but were almost left alone once independently starting to move and talk. In general, there was a large labour participation of children who worked alongside their parents or, if needed, for other families (Salaris 2013). This leads to the hypothesis that the detected differences in the first years of life and the subsequent crossover may be explained by the timing of the elimination process of frail individuals in the two populations. In the Italian population the elimination of frail individuals takes place in the first years of life, while in Villagrande Strisaili it starts from the second year of life and more markedly from age 6 years to adulthood. The doubtable low level of mortality recorded in Villagrande Strisaili therefore corresponds in reality to an excess mortality at subsequent ages that balances the level of mortality in the two populations and makes mortality risk converge to similar values in both populations since at age 50 , i.e. at the onset of the aging process, they record close proportions of survivors.

The occurrence of the second point of intersection in both sexes at age 50 years shifts the attention to the ageing process. In Villagrande Strisaili a mortality deceleration can be observed, and individuals are eliminated at a lower rate compared to their national peers, with differences being more marked for the male population. Selection processes due to ageing mechanisms prove to differ in the examined populations, occurring in Sardinia during a longer period of time and at a slower pace than that observed at early stages of life. Only a life course perspective allows us to observe this result.

Thirdly, in view of the identified mortality differentials it is appropriate to reflect on the possible explanation for these differences and the occurrence of crossovers, which in the literature are generally attributed to ethnicity/race and/or specific causes of deaths (Nam et al., 1978; Nam, 1995; Hummer, 1996; Corti et al., 1999; Johnson, 2000; Hill et al., 2000; Lynch et al., 2003; Thornton, 2004; Stansbury et al., 2005). In the Italian context, it seems more opportune to reflect on genetic differences, rather than on race. From a genetic point of view, Sardinia differs considerably from other European populations (Cavalli-Sforza et al., 1997) and the persistence of these differences to the present has certainly been favoured by its geographical isolation (Sanna, 2006). Genetic studies point out that genes certainly play a role in the aging process, whether these genes are longevity genes or genes involved in the control of age-related diseases (Cadore et al., 2006). In general, the effect of genes was shown not to remain stable but rather to determine a certain level of susceptibility to specific diseases and to death (Christensen et al., 2006). Accordingly, it is plausible to hypothesize that the Sardinian 
population could have favourable genes for a successful aging process in their genetic pool, which implies a reduced susceptibility to certain causes of death (Pilia et al., 2006; Poulain et al., 2011).

Differences in the epidemiological profile between Sardinia and the mainland can be traced back to the past as, according to period data from Unification until the first decades of the $20^{\text {th }}$ century, Sardinia was, with Piedmont and Liguria, one of the regions that recorded better survival estimates at adult ages (i.e. at ages 25-64 years and 65 years and over), particularly with regard to the male population (Caselli, 1987). The available data on mortality by cause for the period 1888-1891 and 1908-1912 allows us to stress that in Sardinia, compared to the national framework, if we exclude the high incidence of deaths due to malaria, lower standardized rates were registered for circulatory system diseases, vascular lesions, and cancer (Pozzi, 2000).

According to more recent investigations, a low level of mortality due to cardiovascular diseases (CVD) at age 80 years and over is recorded in Sardinia (Caselli \& Lipsi, 2006). The role of CVD emerges also in the work of Muntoni et al. (2009) who point out that in spite of the increasing levels of several risk factors (i.e. high blood pressure and smoking habits) mortality for CVD in Sardinia remains low. Undoubtedly the lower incidence of CVD, and related deaths, cannot represent the only cause of "advantage survival" in the aging process of the Sardinian population compared to the mainland, but it certainly plays an important role. However, the findings of this study refer to overall mortality and this does not allow us to speculate further on the possible role of cause specific mortality.
Although the effects of genetics and causes of death are the most investigated, differences in survival cannot be attributed to these two factors alone, but - as demonstrated in numerous studies focusing on different populations around the world - rather appear as the result of a more complex process where the contribution of factors such as lifestyle, physical activity, nutrition, social and family context, religion, external events and physical environment, have been demonstrated to affect individual health status and survival.

Finally, looking at the overall results it is possible to highlight the value of a longitudinal perspective which provides new insights in the interpretation of differential mortality when Sardinia and Italy are compared. It allows the comparison of the survival trajectories of cohorts experiencing the same historical conditions at the same age (Wilmoth et al., 1990). The use of cohort and/or period-cohort data in fact permits better detection and description of differences between populations or subgroups, because parallel life histories and time effects can be considered (Caselli \& Capocaccia, 1989). Particularly, the birth cohorts examined in this study represent those generations that have greatly benefited from changes and improvement in life style in general and medical treatment in particular, unconsciously participating in the epidemiologic transition that has characterized the history of many developed countries during the last century. Understanding the timing of significant changes during the life course provides useful indications of the relevant turning points in the contextual and historical time on which to focus further insights.

\section{Acknowledgements}

The author is very grateful to the Municipality of Villagrande Strisaili, and more precisely to Mrs. Rita Usai and Simona Rubiu, for their invaluable help to this research. My thanks are addressed also to the anonymous reviewers who provided helpful comments on the manuscript. This research was partially supported by the operating programme of the Autonomous Region of Sardinia (PO FSE 2007-2013) according to the LR 7/2007 for the "Promozione della ricerca scientifica e dell'innovazione tecnologica in Sardegna" (Promotion of the Scientific Research and of the Technological Innovation in Sardinia). 


\section{References}

Allard, A., Vallin, J., Andrieux, J. M., \& Robine, J. M. (1996). In search of the secret of centenarians: a demographic and medical survey about centenarians in France. In G. Caselli \& A.D. Lopez (Eds.), Health and mortality among elderly populations (pp. 61-86). Oxford: Clarendon Press.

Angioni, D., Loi, S., \& Puggioni G. (1997). La popolazione dei comuni sardi dal 1688 al 1991. Cagliari: CUEC Editrice.

Barbi, E., Bongaarts, J., \& Vaupel, J.W. (2008). How long do we live? Demographic models and reflections on tempo effects. Berlin: Springer, Demographic Research Monographs 5. http://dx.doi.org/10.1007/978-3-540-78520-0

Bellettini A. (1987). La popolazione italiana: un profilo storico. Torino: Einaudi.

Breschi, M., Esposito, M., Mazzoni, S., \& Pozzi, L. (2012). The Sardinian experience of the lowest Italian infant mortality at the turn of the twentieth century: true or false empirical evidence? Annales de démographie historique, 1, 63-94.

Brooks-Wilson, A.R. (2013). Genetics of healthy aging and longevity. Human Genetics, 132(12), $1323-1338$. http://dx.doi.org/10.1007/s00439-013-1342-z

Cadore, G., Balistreri, C.R., Grimaldi, M.P., Vasto, S., Colonna-Romano, G., Franceschi, C., Lio, D., Caselli, G., \& Caruso, C. (2006). Immunogenetics, gender, and longevity. Annals of New York Academy of Sciences, 1089(1), 516-537. http://dx.doi.org/10.1196/annals.1386.051

Cannas, A. (2007). Biddamanna, vida longa. Villagrande Strisaili, paese di longevi. Elmas: Arti grafiche Pisano srl.

Carnes, B.A., Olshansky, S.J., \& Grahn, D.A. (2003). Biological evidence for limits to the duration of life. Biogerontology, 4(1), 31-45. http://dx.doi.org/10.1023/A:1022425317536

Caselli, G. (1987). Mortalità e sopravvivenza in Italia dall'Unità gli anni 30. In Si.De.S (Eds.) Popolazione, società e ambiente. Temi di Demografia storica italiana (secc. XVII-XIX) (pp. 275-310). Bologna: CLUEB.

Caselli, G., \& Capocaccia, R. (1989). Age, period, cohort and early mortality: an analysis of adult mortality in Italy. Population Studies, 43(1), 133-153. http://dx.doi.org/10.1080/0032472031000143886

Caselli, G., \& Lipsi, R.M. (2006). Survival differences among the oldest old in Sardinia: who, what, where, and why? Demographic Research, 14(13), 267-294. http://dx.doi.org/10.4054/DemRes.2006.14.13

Caselli, G., Pozzi, L., Vaupel, J. W., Deiana, L., Pes, G. M., Carru, C., Franceschi, C., \& Baggio, G. (2006). Family clustering in Sardinian longevity: a genealogical approach. Experimental Gerontology, 41(8), 727-736. http://dx.doi.org/10.1016/j.exger.2006.05.009

Cavalli-Sforza, L.L., Menozzi, P., \& Piazza A. (1997). Storia e geografia dei geni umani. Milano: Adelphi Edizioni.

Cheung, S.L.K., \& Robine, J-M. (2007). Increase in common longevity and the compression of mortality: the case of Japan. Population Studies: a Journal of Demography, 61(1), 85-97. http://dx.doi.org/10.1080/00324720601103833

Christensen, K., Johnson, T.E., \& Vaupel J.W. (2006). The quest for genetic determinants of human longevity: challenges and insights. Nature, 7(6), 436-448.

Coale, A.J., \& Kisker, E.E. (1986). Mortality crossovers: reality or bad data? Population Studies, 40(3), 389401. http://dx.doi.org/10.1080/0032472031000142316

Coles, L. S. (2003). Table of the world-wide living supercentenarians. Journal of Anti-Aging Medicine, 6(1), 6568. http://dx.doi.org/10.1089/109454503765361597

Coletti, F. (1908). La mortalità nei primi anni d'età e la vita sociale della Sardegna. Torino: Fratelli Bocca Editori.

Corti, M.C., Guralnik, J.M., Ferrucci, L., Izmirlian, G., Leveille, S.G., Pahor, M., Cohen, H.J., Pieper, C., \& Havlik, R.J. (1999). Evidence for a Black-White crossover in all-cause and coronary heart disease mortality in an older population: the North Carolina EPESE. American Journal of Public Health, 89(3), 308-314. http://dx.doi.org/10.2105/AJPH.89.3.308

Davinelli, S., Willcox, D.C., \& Scapagnini, G. (2012). Extending healthy ageing: nutrient sensitive pathway and centenarian population. Immunity \& Ageing, 9(9), 1-7.

Deiana, L., Ferrucci, L., Pes, G.M., Carru, C., Delitala, G., Ganau, A., Mariotti, S., Nieddu, A., Pettinato, S., Putzu, P., Franceschi, C., \& Baggio, G. (1999). AKEntAnnos. The Sardinia study of extreme longevity. Aging Clinical and Experimental Research, 11(3), 77-84.

Elo, I.T., \& Preston, S.H. (1992). Effects of early-life conditions on adult mortality: a review. Population Index, 58(2), 186-212. http://dx.doi.org/10.2307/3644718

Esposito, M. (2012). Previsioni provinciali e comunali della popolazione della Sardegna. In M. Breschi (Ed.), Dinamiche demografiche in Sardegna. Tra passato e futuro. Udine: Forum Editrice. 
Ewbank, D. (1981). Age misreporting and age selective underenumeration: sources, patterns, and consequences for demographic analysis. Washington DC: National Academic Press. Committee on Population and Demography, Report 4.

Franceschi, C., Bezrukov, V., Blanché, H., Bolund, L., Christensen, K., De Benedictis, G., Deiana, L., Gonos, E., Hervonen, A., Yang, H., Jeune, B., Kirkwood, T.B., Kristensen, P., Leon, A., Pelicci, P.G., Peltonen, L., Poulain, M., Rea, I.M., Remacle, J., Robine, J.M., Schreiber, S., Sikora, E., Slagboom, P.E., Spazzafumo, L., Stazi, M.A., Toussaint, O., \& Vaupel, J. W. (2007). Genetics of healthy aging in Europe: the EUintegrated project GEHA (GEnetics of Healthy Aging). Annals of New York Academic Sciences, 1100, 21-45. http://dx.doi.org/10.1196/annals.1395.003

Franceschi, C., Motta, L., Valensin, S., Rapisarda, R., Franzone, A., Berardelli, M., Motta, M., Monti, D., Bonafe, M., Ferrucci, L., Deiana, L., Pes, G. M., Carru, C., Desole, M. S., Barbi, C., Sartoni, G., Gemelli, C., Lescai, F., Olivieri, F., Marchegiani, F., Cardelli, M., Cavallone, L., Gueresi, P., Cossarizza, A., Troiano, L., Pini, G., Sansoni, P., Passeri, G., Lisa, R., Spazzafumo, L., Amadio, L., Giunta, S., Stecconi, R., Morresi, R., Viticchi, C., Mattace, R., De Benedictis, G., \& Baggio, G. (2000). Do men and women follow different trajectories to reach extreme longevity? Italian Multicenter Study on Centenarians (IMUSCE). Aging Clinical and Experimental Research, 12(2), 77-84. http://dx.doi.org/10.1007/BF03339894

Fraumene, C., Petretto, E., Angius, A., \& Pirastu, M. (2003). Striking differentiation of sub-populations within a genetically homogeneous isolate (Ogliastra) in Sardinia as revealed by mtDNA analysis. Human Genetics, 114(1), 1-10. http://dx.doi.org/10.1007/s00439-003-1008-3

Gatti, A.M. (2002). La mortalità infantile tra Ottocento e Novecento. La Sardegna nel panorama italiano. Quaderni del Dipartimento di Ricerche Economiche e Sociali, no. 13, University of Cagliari, Cagliari.

Gatti, A.M., \& Puggioni G. (1998). Storia della popolazione dal 1847 ad oggi. In L. Berlinguer \& A. Mattone (Eds.) Storia d'Italia. Le regioni, dall'Unità ad oggi (pp. 1039-1079). Vol. La Sardegna. Torino: Einaudi.

Gatti, A.M., \& Salaris, L. (2004). Grandi vecchi in Sardegna tra Ottocento e Duemila. La longevità attraverso i Censimenti della popolazione. Quaderni del Dipartimento di Ricerche Economiche e Sociali, no. 19, University of Cagliari, Cagliari.

Gavrilov, L.A., \& Gavrilova, N.S. (2001). When does human longevity start? Demarcation of the boundaries for human longevity. Journal of Anti-Aging Medicine, 4(2), 115-124. http://dx.doi.org/10.1089/10945450152466161

Glei, D.A. (2009). About mortality data for Italy. Human Mortality Database. http://www.mortality.org/hmd/ITA/InputDB/ITAcom.pdf. Last access on January 15, 2012

Hill, M.E., Preston, S.H., \& Rosenwaike, I. (2000). Age reporting among white Americans aged 85+: results of a record linkage study. Demography, 37(2), 175-186. http://dx.doi.org/10.2307/2648119

Hirsch, H.R., Liu, X., \& Witten T.M. (2000). Mortality-rate crossovers and maximum lifespan in advantaged and disadvantaged populations: accelerated-mortality and sudden-death models. Journal of Theoretical Biology, 205(2), 171-180. http://dx.doi.org/10.1006/jtbi.2000.2063

HMD - Human Mortality Database, web-site: www.mortality.org. Last access on August 10, 2012

Hoffmann, R. (2005). Does the socioeconomic mortality gradient interact with age? Evidence from US survey data and Danish register data. Max Planck Institute for Demographic Research - MPIDR Working paper, 020.

Hummer, R.A. (1996). Black-white differences in health and mortality: a review and conceptual model. Sociological Quarterly, 37(1), 105-125. http://dx.doi.org/10.1111/j.1533-8525.1996.tb02333.x

ISTAT (2014). Popolazione residente per età, sesso e stato civile al $1^{\circ}$ Gennaio 2013, web-site: http://demo.istat.it/pop2013/index. html. Last access on March 6, 2014

Jeune, B., \& Vaupel, J.W. (1995). Exceptional longevity: from prehistory to the present. Odense: Odense University Press, Odense Monographs on Population Aging, 2.

Johnson, N.E. (2000). The racial crossover in comorbidity, disability, and mortality. Demography, 37(3), 267283. http://dx.doi.org/10.2307/2648041

Kannisto, V. (1996). The advancing frontier of survival. Odense: Odense University Press, Monographs on Population Aging, 3.

Lampis, R., Morelli, L., De Virgilis, S., Congia, M., \& Cucca, F. (2000). The distribution of HLA aplotypes reveals that the Sardinian population is genetically differentiated from the other Caucasian populations. Tissue Antigenes, 56(6), 515-521. http://dx.doi.org/10.1034/j.1399-0039.2000.560605.x

Liu, X. \& Witten, T.M. (1995). A biologically based explanation for mortality crossover in human populations. The Gerontologist, 35(5), 609-615. http://dx.doi.org/10.1093/geront/35.5.609 
Liu, X., Engel, C.C., Armstrong, D.W., \& Kang, H. (2008). Survival convergence and the preceding mortality crossover for two population subgroups. Population Research Policy Review, 27(3), 293-306. http://dx.doi.org/10.1007/s11113-007-9063-4

Lynch, S.M., Brown J.S., \& Harmsen K.G. (2003). Black-white differences in mortality compression and deceleration and the mortality crossover reconsidered. Research on Aging, 25(5), 456-483. http://dx.doi.org/10.1177/0164027503254675

Maier, H., Gampe, J., Jeune, B., Robine, J-M., \& Vaupel, J.W. (2010). Supercentenarians. Berlin: Springer, Demographic Research Monographs, 7. http://dx.doi.org/10.1007/978-3-642-11520-2

Meslé, F., \& Vallin, J. (2002). Improving the accuracy of life tables for the oldest old: the case of France. Population, 57(4-5), 601-629.

Meslé, F., \& Vallin, J. (2009). The segmented trend line of highest life expectancies. Population and Development Review, 35(1), 159-187. http://dx.doi.org/10.1111/j.1728-4457.2009.00264.x

Muntoni, S., Atzori, L. Mereu, R., Manca, A., Satta, G., Gentilini, A., Bianco, P., Baule, A., Baule, G.M., \& Muntoni, S. (2009). Risk factors for cardiovascular disease in Sardinia from 1978 to 2001: a comparative study with Italian mainland. European Journal of Internal Medicine, 20(4), 373-377. http://dx.doi.org/10.1016/j.ejim.2008.10.007

Murabito, J.M., Yuan, R., \& Lunetta K.L. (2012). The search for longevity and healthy aging genes: insights from epidemiological studies and samples of long-lived individuals. Journal of Gerontology. Biological Sciences and Medical Sciences, 67(5), 470-479. http://dx.doi.org/10.1093/gerona/gls089

Nam, C.B. (1995). Another look at mortality crossover. Social Biology, 42(1-2), 133-142.

Nam, C.B., Weatherby, N.L., \& Ockay, K.A. (1978). Causes of death which contribute to the mortality crossover effect. Social Biology, 25(4), 306-314.

Olshansky, S.J., Carnes, B.A., \& Cassel, C. (1990). In search of Methuselah: estimating the upper limits to human longevity. Sciences, 250(4981), 634-640. http://dx.doi.org/10.1126/science.2237414

Orrù, A. (2011). Analisi demografica della longevità in Sardegna. PhD Thesis in Biology and biochemistry of humans and of environment. University of Cagliari, Cagliari.

Parsons, P.A. (1996). The limit to human longevity: an approach through a stress theory of ageing. Mechanisms of Ageing and Development, 87(3), 211-218. http://dx.doi.org/10.1016/0047-6374(96)01710-1

Passarino, G., Underhill, P.A., Cavalli-Sforza, L.L., Semino, O., Pes, G.M., Carru, C., Ferrucci, L., Bonafè, M., Franceschi, C., Deiana, L., Baggio, G., \& De Benedictis, G. (2001). Y chromosome binary markers to study the high prevalence of males in Sardinian centenarians and the genetic structure of the Sardinian population. Human Heredity, 52(3), 136-139. http://dx.doi.org/10.1159/000053368

Pes, G.M., Tolu, F., Poulain, M., Errigo, A., Masala, S., Pietrobelli, A., Battistini, N. C., \& Maioli, M. (2013). Lifestyle and nutrition related to male longevity in Sardinia: an ecological study. Nutrition, Metabolism and Cardiovascular Diseases, 23(3), 212-219. http://dx.doi.org/10.1016/j.numecd.2011.05.004

Pilia, G., Chen, W-M., Scuteri, A., Orrù, M., Albai, G., Dei, M., Lai, S., Usala, G., Lai, M., Loi, P., Mameli, C., Vacca, L., Deiana, M., Olla, N., Masala, M., Cao, A., Najjar, S.S., Terracciano, A., Nedorezov, T., Sharov, A., Zonderman, A.B., Abecasis, G.R., Costa, P., Lakatta, E., \& Schlessinger, D. (2006). Heritability of cardiovascular and personality traits in 6,148 Sardinians. PLoS Genetics, 2(8), 12071223. http://dx.doi.org/10.1371/journal.pgen.0020132

Poulain, M. (2011). Exceptional longevity in Okinawa. A plea for in-depth validation. Demographic Research, 25(7), 245-84. http://dx.doi.org/10.4054/DemRes.2011.25.7

Poulain, M., \& Naito, K. (2004). L'évolution de la longévité à Okinawa, 1921-2000. Cahiers québécois de demographie, 33(1), 29-49. http://dx.doi.org/10.7202/010851ar

Poulain, M., Pes, G.M., Grasland, C., Carru, C., Ferrucci, L., Baggio, G., Franceschi, C., \& Deiana, L. (2004). Identification of a geographic area characterized by extreme longevity in the Sardinia island: the AKEA study. Experimental Gerontology, 39(9), 1423-1429. http://dx.doi.org/10.1016/j.exger.2004.06.016

Poulain, M., Pes, G.M., \& Salaris, L. (2011). A population where men live as long as women: Villagrande Strisaili, Sardinia. Journal of Aging Research, 1-10. http://dx.doi.org/10.4061/2011/153756

Poulain, M., Herm, A., \& Pes, G.M. (2013). The Blue Zones: areas of exceptional longevity around the world. Vienna Yearbook of Population Research, 11, 87-108.

Pozzi, L. (2000). La lotta per la vita. Evoluzione e geografia della sopravvivenza in Italia fra '800 e '900. Udine: Forum Editrice.

Preston, S.H., Elo, I.T., \& Preston, S.H. (1999). Effects of age misreporting on mortality estimates at older ages. Population Studies: a Journal of Demography, 53(2), 165-177. http://dx.doi.org/10.1080/00324720308075 
Preston, S.H., Heuveline, P., \& Guillot, M. (2001). Demography. Measuring and modelling population processes. Oxford: Blackwell Publishers.

Rehkopf D.H., Dow, W.H., Rosero-Bixby, L., Lin, J., Epel, E.S., \& Blackburn, E.H. (2013). Longer leukocyte telomere length in Costa Rica's Nicoya Peninsula: a population-based study. Experimental Gerontology, 48(11), 1266-1273. http://dx.doi.org/10.1016/j.exger.2013.08.005

Robine, J-M., Vaupel, J.W., Jeune, B., \& Allard, M. (1997). Longevity: to the limits and beyond. Berlin: Springer, Research and Perspectives in Longevity.

Robine, J-M., Saito, Y., \& Jagger, C. (2003). The emergence of extremely old people: the case of Japan. Experimental Gerontology, 38(7), 735-739. http://dx.doi.org/10.1016/S0531-5565(03)00100-1

Robine, J-M., \& Caselli, G. (2005). An unprecedented increase in the number of centenarians. GENUS, LXI (1), 57-82.

Rosero-Bixby, L. (2008). The exceptionally high life expectancy of Costa Rican nonagenarians. Demography, 45(3), 673-691. http://dx.doi.org/10.1353/dem.0.0011

Salaris, L. (2010). Searching for longevity determinants: following survival of newborns in an in-land village of Sardinia (1866-2006). SIS Best PhD Theses in Statistics and Applications - Demography. Padova: CLEUP.

Salaris, L. (2013). Riflessioni sulle pratiche dell'allattamento e dello svezzamento in Sardegna nei secoli XIXXX: un'analisi qualitativa. In M. Breschi and L. Pozzi (Eds.) Mortalità e stato di salute dalla nascita alla prima adolescenza. Indagini micro in Italia secoli XIX-XX (pp. 135-155). Udine: Forum Editrice.

Salaris, L. (2014). Differential mortality in a long-living community in Sardinia (Italy): a cohort analysis. Journal of Biosocial Science, 1-15. http://dx.doi.org/10.1017/S0021932014000224

Salaris, L., Tedesco, N., \& Poulain, M. (2013). Familial transmission of human longevity: a population-based study in an inland village of Sardinia (Italy), 1850-2010. Vienna Yearbook of Population Research, 11, 325-49.

Sanna, E. (2006). Il popolamento della Sardegna e le origini dei Sardi. Cagliari: CUEC.

Sautter, J.M., Thomas, P.A., Dupre, M.E., \& George, L.K. (2012). Socioeconomic status and the Black-White mortality crossover. American Journal of Public Health, 102(8), 1566-1571. http://dx.doi.org/10.2105/AJPH.2011.300518

Scherbov, S., \& Ediev, D. (2011). Significance of life table estimates for small populations: simulation-based study of standard errors. Demographic Research, 24(22), 527-550. http://dx.doi.org/10.4054/DemRes.2011.24.22

Scuteri, A., Najjar, S.S., Orrù, M., Albai, G., Strait, J., Tarasov, K. V., Piras, M. G., Cao, A., Schlessinger, D., Uda, M., \& Lakatta, E.G. (2009). Age- and gender-specific awareness, treatment, and control of cardiovascular risk factors and subclinical vascular lesions in a founder population: the SardiNIA Study. Nutrition, Metabolism \& Cardiovascular Diseases, 19(8), 532-541. http://dx.doi.org/10.1016/j.numecd.2008.11.004

Song, S. (2010). Mortality consequences of the 1959-1961 great leap forward famine in China: debilitation, selection, and mortality crossovers. Social Science and Medicine, 71(3), 551-558. http://dx.doi.org/10.1016/j.socscimed.2010.04.034

Stansbury, J.P., Jia, H., Williams, L. S., Vogel, W. B., \& Duncan P. W. (2005). Ethnic disparities in stroke: epidemiology, acute care, and postacute outcomes. Stroke, 36(2), 374-386. http://dx.doi.org/10.1161/01.STR.0000153065.39325.fd

Strait, J.B., Uda, M., Lakatta E.G., \& Najjar, S.S. (2009). Utilizing new tools to define the genetic underpinnings of risky traits associated with coronary artery disease: the SardiNIA Study. Trends in Cardiovascular Medicine, 19(3), 69-75. http://dx.doi.org/10.1016/j.tcm.2009.05.001

Thornton, R. (2004). The Navajo-U.S. population mortality crossover since the mid-20th century. Population Research and Policy Review, 23 (3), 291-308. http://dx.doi.org/10.1023/B:POPU.0000034094.47041.52

Tognotti, E. (1996). La malaria in Sardegna. Per una storia del paludismo nel Mezzogiorno (1880-1950). Roma: Franco Angeli Edizioni.

Vaupel, J.W. (2000). Setting the stage: a generation of centenarians? The Washington Quarterly, 23(3), 197200. http://dx.doi.org/10.1162/016366000561097

Vaupel, J.W., Manton, K.G., \& Stallard, E. (1979). The impact of heterogeneity in individual frailty on the dynamics of mortality. Demography, 16(3), 439-454. http://dx.doi.org/10.2307/2061224

Vaupel, J.W., \& Robine, J-M. (2002). Emergence of supercentenarians in low-mortality countries. North American Actuarial Journal, 6(3), 54-63. http://dx.doi.org/10.1080/10920277.2002.10596057

Willcox, B.J., Willcox, D.C., \& Suzuki, M. (2001). The Okinawa program: how the world's lived people achieve everlasting health and how you can too. New York: Clarkson Potter Publishers. 
Willcox, D.C., Willcox, B.J., Hsueh, W-C., \& Suzuki, M. (2006). Genetic determinants of exceptional human longevity: insights from the Okinawa Centenarian Study. Age, 28(4), 313-332. http://dx.doi.org/10.1007/s11357-006-9020-x

Wilmoth, J.R., Vallin, J., \& Caselli, G. (1990). When does a cohort's mortality differ from what we might expect? Population: An English Selection, 2, 93-126.

Wilmoth, J.R., Andreev, K., Jdanov, D., \& Glei D.A. (2007). Methods protocol for the Human Mortality Database. http://www.mortality.org/Public/Docs/Metho dsProtocol.pdf. Last access on January 15, 2012

Wrigley-Field, E. (2012). Mortality deceleration and mortality selection: three unexpected implications of a simple model. Paper presented at Population Association of America Meeting, San Francisco, May 35, 2012.

Yao, L., \& Robert S.A. (2011). Examining the racial crossover in mortality between African American and White older adults: a multilevel survival analysis of race, individual socioeconomic status, and neighbourhood socioeconomic context. Journal of Aging Research, 1-8. http://dx.doi.org/10.4061/2011/132073

Zarulli, V. (2012) Mortality shocks and the human rate of aging. Max Planck Institute for Demographic Research - MPIDR Working Paper, 019. 